\title{
Effect of Zhongyi paste on inflammatory pain in mice by regulation of the extracellular regulated protein kinases 1/2- cyclooxygenase-2-prostaglandin $\mathrm{E}_{2}$ pathway
}

\author{
Ailan $\mathrm{Xiao}^{1, *}$, Chuncao $\mathrm{Wu}^{2, *}$, Lei Kuang ${ }^{1}$, Weizhong $\mathrm{Lu}^{1}$, Xin $\mathrm{Zhao}^{3}$, Zhiping Kuang ${ }^{1}$, and $\mathrm{Na} \mathrm{Hao}{ }^{1}$ \\ 'The First Department of Orthopaedic Surgery, Chongqing Traditional Chinese Medicine Hospital, Chongqing, China \\ ${ }^{2}$ Office of Academic Research, Chongqing Traditional Chinese Medicine Hospital, Chongqing, China \\ ${ }^{3}$ Chongqing Collaborative Innovation Center for Functional Food, Chongqing University of Education, Chongqing, China
}

Received June 25, 2020

Revised August 19, 2020

Accepted August 19, 2020

Handling Editor: Jong Yeon Park

\author{
Correspondence \\ Zhiping Kuang \\ China \\ Tel: +86-23-6265-3650 \\ Fax: +86-23-6265-3650 \\ E-mail: kuangzp@cqff.ac.cn
}

The First Department of Orthopaedic

Surgery, Chongqing Traditional Chinese Medicine Hospital, 6 Panxi 7 Branch Rd, Jiangbei district, Chongqing 400021,

$\mathrm{Na} \mathrm{Hao}$

The First Department of Orthopaedic Surgery, Chongqing Traditional Chinese Medicine Hospital, 6 Panxi 7 Branch Rd, Jiangbei district, Chongqing 400021,

China

Tel: +86-23-67983652

Fax: +86-23-67983652

E-mail: haona@cqff.ac.cn

*Ailan Xiao and Chuncao Wu contributed equally to this work.
Background: Zhongyi paste is a traditional Chinese medicine herbal paste that is externally applied to reduce inflammation and relieve pain.

Methods: An acute foot swelling inflammation model in C57BL/6J mice was established by carrageenan-induced pathogenesis. Zhongyi paste raised the pain threshold and also reduced the degree of swelling in mice with carrageenan-induced foot swelling.

Results: Analysis indicated that serum tumor necrosis factor-alpha, interleukin-1 beta, and prostaglandin $E_{2}\left(P G E_{2}\right)$ cytokine levels and $P G E_{2}$ levels in the paw tissue of the mice were decreased by Zhongyi paste treatment. The quantitative polymerase chain reaction and western blot results showed that Zhongyi paste downregulated the mRNA and protein expression of extracellular signal-regulated kinase $1 / 2$ (ERK1/2), and cyclooxygenase-2 (COX-2), and also downregulated the mRNA expression of $\mathrm{PGE}_{2}$. At the same time, the Zhongyi paste exerted a stronger effect as an external drug than that of indomethacin, which is an oral drug, and voltaren, which is an externally applied drug.

Conclusions: Our results indicated that Zhongyi paste is a very effective drug to reduce inflammatory swelling of the foot, and its mechanism of action is related to regulation of the ERK1/2-COX-2-PGE 2 pathway.

Key Words: Biochemistry; Cyclooxygenase 2; Herbal Medicine; Inflammation; Medicine, Chinese Traditional; Mitogen-Activated Protein Kinase 3; Pain; RNA, messenger.

\section{INTRODUCTION}

Inflammation refers to the complex defense response of vascular system tissue to external, harmful stimulation, which is an important pathological process in the body. Usually, the manifestations of inflammation are redness, swelling, heat, pain, and dysfunction [1], and the pain, swelling, and other symptoms often become chronic. In (a) This is an open-access article distributed under the terms of the Creative Commons Attribution Non-Commercial License (http://creativecommons.org/licenses/by-nc/4.0/), which permits unrestricted non-commercial use, distribution, and reproduction in any medium, provided the original work is properly cited.

(C) The Korean Pain Society, 2020
Author contributions: Ailan Xiao: Writing/manuscript preparation; Chuncao Wu: Methodology; Lei Kuang: Data curation; Weizhong Lu: Data curation; Xin Zhao: Data curation; Zhiping Kuang: Writing/manuscript preparation; Na Hao: Writing/manuscript preparation. 
severe cases, it will affect normal daily activities and reduce quality of life. At present, the development of inflammatory pain drugs is mainly focused on non-opioid drugs, especially non-steroidal anti-inflammatory and analgesic drugs, but they are limited by their addictive properties, serious cardiovascular effects, and other side effects [24]. Some externally used drugs will cause skin allergies, and possess other undesirable traits [5]. Compared with chemical drugs, extracts of natural substances have the advantages of low development cost and few side effects.

Zhongyi paste is an external traditional Chinese medicine, and it has been improved by applying modern technology to the traditional Chinese medicine formula. All the ingredients used in Zhongyi paste are derived from natural plants. Extracts from more than ten different natural plants are used in certain proportions to obtain a paste-like medicine that has been clinically verified to be beneficial for arthritis [6]. However, no studies have been conducted to determine the mechanism of Zhongyi paste. The carrageenan-induced foot-swelling model in rodents is the most commonly used acute inflammatory model to evaluate the activity of anti-inflammatory drugs [7].

The inflammatory process of foot swelling induced by carrageenan can be divided into two stages: in the early stage of inflammation, histamine, 5-hydroxytryptamine, bradykinin, and a small amount of prostaglandins are released from local tissues; in the later stage, neutrophil infiltration occurs, and a large amount of prostaglandins is produced [8]. Neutrophils can release inflammatory factors and participate in the body's defense response. Inflammatory factors themselves not only damage the body cells, but also induce other cells to produce additional inflammatory factors, resulting in a more severe inflammatory response [9].

Prostaglandin $\mathrm{E}_{2}\left(\mathrm{PGE}_{2}\right)$ plays an important role in the regulation of inflammatory factors. It is produced by arachidonic acid under the catalysis of cyclooxygenase-2 (COX-2) and other proteases [10]. The hyperphosphorylation of extracellular signal-regulated kinase 1/2 (ERK1/2) stimulates the expression of COX-2, promotes the release of $\mathrm{PGE}_{2}$, and then stimulates and mediates the occurrence and development of inflammatory pain [11]. The ERK1/2COX-2-PGE 2 pathway is closely related to foot swelling and inflammation [12].

In the current study, an acute foot swelling and inflammation model using C57BL/6J mice, induced by carrageenan, was created to study the effect of Zhongyi paste on foot swelling and inflammation, and the regulatory role of the ERK1/2-COX-2-PGE 2 pathway. Through this study, we can observe the mechanism of action of the Zhongyi paste, improve its technology and efficacy, and develop a more scientific application of the ointment for more optimal results.
Table 1. Composition of Traditional Chinese Medicine in Zhongyi Paste

\begin{tabular}{|c|c|c|}
\hline $\begin{array}{l}\text { Chinese medicine } \\
\text { name }\end{array}$ & Scientific name & $\begin{array}{l}\text { Amount } \\
\text { (g) }\end{array}$ \\
\hline Trichosanthin & Root of Trichosanthes kirilowii Maxim. & 250 \\
\hline Phellodendron & $\begin{array}{l}\text { Bark of Phellodendron chinense } \\
\text { Schneid. }\end{array}$ & 30 \\
\hline Chinese rhubarb & Rheum palmatum L. & 30 \\
\hline Turmeric & Curcuma longa L. & 30 \\
\hline Angelica dahurica & $\begin{array}{l}\text { Angelica dahurica (Fisch. ex Hoffm.) } \\
\text { Benth. et Hook. f. ex Franch. et Sav }\end{array}$ & 30 \\
\hline Chinese atractylodes & $\begin{array}{l}\text { Root of Atractylodes lancea (Thunb.) } \\
\text { DC }\end{array}$ & 30 \\
\hline Tangerine peel & Peel of Citrus reticulata Blanco & 40 \\
\hline Licorice & Glycyrrhiza uralensis Fisch & 40 \\
\hline Arisaema & Arisaema heterophyllum Blume & 40 \\
\hline Magnolia officinalis & $\begin{array}{l}\text { Peel of Magnolia officinalis Rehd. et } \\
\text { Wils }\end{array}$ & 40 \\
\hline
\end{tabular}

All traditional Chinese medicine plants are dry. After being ground, $20 \mathrm{~g}$ of vaseline and $100 \mathrm{~mL}$ of vegetable oil were added to the above durgs, heated to $120^{\circ} \mathrm{C}$, then filtered and cooled to about $60^{\circ} \mathrm{C}$. The dosage in the table is for one person, the dosage of mice was $1 / 1,500$ of that of human.

\section{MATERIALS AND METHODS}

\section{Production technology of Zhongyi paste}

Ten traditional Chinese medicine plants (Table 1) as well as gypsum (1,600 g), red lead (40 g), and borneol (80 g) were ultrafine comminuted and mixed. When a mixture of vaseline and vegetable oil was heated to $120^{\circ} \mathrm{C}$ and cooled to $60^{\circ} \mathrm{C}$, the comminuted powder of traditional Chinese medicine was added and stirred until it was condensed.

\section{Foot model of swelling and inflammation}

Fifty six-week-old C57BL/6J mice (half male and half female) were randomly divided into five groups: the normal group, model group, indomethacin group, voltaren (diclofenac diethylamine emulsion) group, and Zhongyi paste group, with 10 mice in each group. One week after adaptive feeding, the right hind paw of the mice in the normal group were injected subcutaneously into the plantar tissues with $25 \mu \mathrm{L} 0.9 \%$ saline. The subcutaneous tissues of the right hind paws of the other groups of mice were injected with $25 \mu \mathrm{L} 1 \%$ (w/v) carrageenan solution to induce acute swelling of the foot. Immediately afterward, administration of $10 \mathrm{mg} / \mathrm{kg}$ (body weight) indomethacin by gavage was performed for the mice in the indomethacin group; the right paws of the mice in the voltaren and Zhongyi paste groups were evenly coated with $0.2 \mathrm{~g}$ voltaren or Zhongyi paste (Table 1), respectively, and after application of the drug, the right paws of all mice except the normal 
group were wrapped with gauze [13]. The right paws of the mice were then observed hourly for 5 hours, and then, the mice were killed by cervical amputation, and the whole blood and right paw of the mice were harvested for experimentation. This study was approved by the ethics committee of Chongqing Functional Food Collaborative Innovation Center, Chongqing University of Education, China (201911035B).

\section{Determination of pain threshold by the hot plate method}

The hot-plate method uses thermal stimulation to produce pain in mice. The mice were placed on a $55^{\circ} \mathrm{C}$ hot plate to stimulate a painful reaction in the foot, i.e., a licking reaction. The time of licking (latency) in mice was used as an indicator of the pain response to determine whether the drug had an antihyperalgesic effect. The latency of the mice in each group was determined before administration of the drugs, and again 5 hours after the injection of carrageenan to evaluate the antihyperalgesic effect of drugs on the carrageenan-induced foot swelling in the mice [14].

\section{Measurement of foot swelling in mice}

The right hind paw volume of the mice was measured at 5 hours after injection of carrageenan or saline. Seventy $\mathrm{mL}$ pure water was added into the measuring cup of the paw volume meter (KW-7C; Nanjing Calvin Biotechnology Co., Ltd, Nanjing, Jiangsu, China, Fig. 1). The mouse ankle joint was marked. The mouse's hind knee joint was held by hand to make the hind foot straighten. Then it was slowly put into the measuring cup. When the horizontal plane

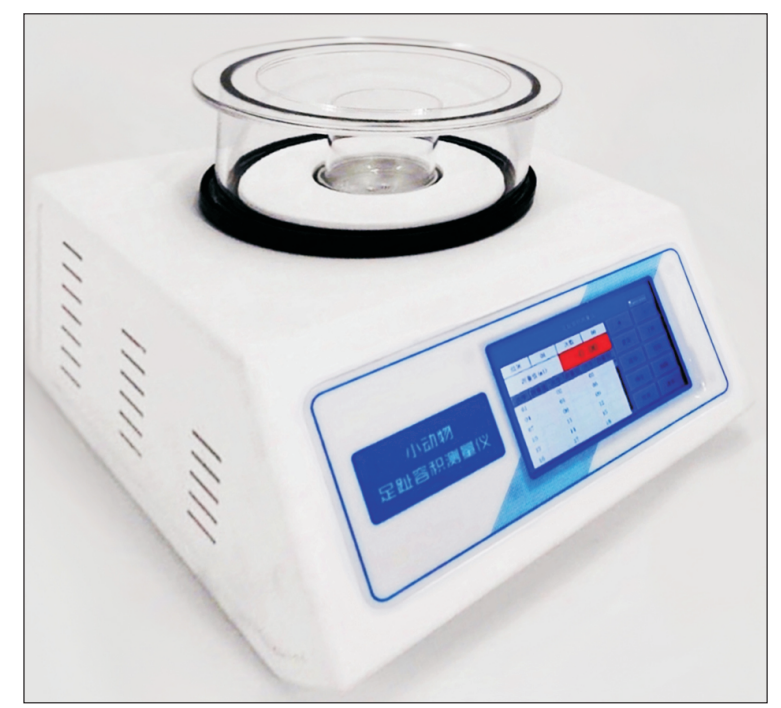

Fig. 1. The paw volume meter in this study. Paw volume meter: KW-7C, Nanjing Calvin Biotechnology Co., Ltd, Nanjing, Jiangsu, China. overlapped with the measurement mark on the mouse foot, the measurement of was carried out [15].

\section{Detection of serum tumor necrosis factor-alpha (TNF- $\alpha$ ) and interleukin-1 beta (IL-1 $\beta$ ) cytokine levels}

After 5 hours of inducing foot swelling the blood was collected from the mice using the retro-orbital blood sampling method [16], then the mice were killed by neck amputation. The blood was centrifuged at $3,000 \mathrm{rpm}$ for 10 minutes after 30 minutes at $4^{\circ} \mathrm{C}$ and the supernatant serum was collected. The serum levels of TNF- $\alpha$ and IL-1 $\beta$ were detected using enzyme-linked immunosorbent assay (ELISA) kits (Nanjing Jiancheng Bioengineering Institute, Nanjing, Jiangsu, China).

\section{Detection of mRNA expression in injured foot tissues by quantitative reverse transcription- polymerase chain reaction (qRT-PCR)}

TRIzol reagent was used to extract total RNA from right hind plantar tissues. For the reaction, $1 \mu \mathrm{L}$ of Oligo(dT), 18 $\mu \mathrm{L}$ of primer with a concentration of $500 \mathrm{ng} / \mu \mathrm{L}$, and $1.0 \mu \mathrm{L}$ of total RNA with a concentration of $1.0 \mu \mathrm{g} / \mu \mathrm{L}$ were added to $10.0 \mu \mathrm{L}$ of nuclease-free water and then heated at $65^{\circ} \mathrm{C}$ for 5 minutes. Next, $4.0 \mu \mathrm{L}$ of $5 \times$ reaction buffer, $1.0 \mu \mathrm{L}$ of ribocock RNase inhibitor with a concentration of $20 \mathrm{U}$, $2.0 \mu \mathrm{L}$ of $10 \mathrm{mM}$ dNTP Mix, and $1.0 \mu \mathrm{L}$ of reveraid reverse transcriptase with a concentration of $200 \mathrm{U} / \mu \mathrm{L}$ were added to the above reaction system solution for transcription of cDNA at $42^{\circ} \mathrm{C}$ for 60 minutes and $70^{\circ} \mathrm{C}$ for 5 minutes. Then, $1.0 \mu \mathrm{L}$ of this reaction body fluid was added to $1 \mu \mathrm{L}$ of 10.0 $\mu \mathrm{M}$ upstream primer, $1 \mu \mathrm{L}$ of $10.0 \mu \mathrm{M}$ downstream primer (Table 2) and $7.0 \mu \mathrm{L}$ of sterile double-distilled water for amplification. The reaction conditions were denaturation at $95^{\circ} \mathrm{C}$ for 3 minutes, annealing at $60^{\circ} \mathrm{C}$ for 30 secconds,

Table 2. Sequences of Primers Used in the Quantitative Polymerase Chain Reaction Assay

\begin{tabular}{cl}
\hline Gene name & \multicolumn{1}{c}{ Sequence } \\
\hline ERK1/2 & Forward: 5'-TCAAGCCTCCAACCTC-3' \\
& Reverse: 5'-GCAGCCCACAGACCAAA-3' \\
COX-2 & Forward: 5'-CATCCCCTCCTGCGAAGTT-3' \\
& Reverse: 5'-CATGGGAGTTGGCAGTCAT-3' \\
PGE $_{2}$ & Forward: 5'-TGGAGGTGAATCCCGTGAGA-3' \\
& Reverse: 5'-AAACTCGGTCACCTCCTGC-3' \\
GAPDH & Forward: 5'-AGGTCGGTGTGAACGGATTG-3' \\
& Reverse: 5'-GGGGTCGTTGATGGCAACA-3' \\
\hline
\end{tabular}

ERK1/2: extracellular signal-regulated kinase 1/2, COX-2: cyclooxygenase-2, $\mathrm{PGE}_{2}$ : prostaglandin $\mathrm{E}_{2}$, GAPDH: glyceraldehyde 3-phosphate dehydrogenase. 
and extension at $95^{\circ} \mathrm{C}$ for 1 minute, for 40 cycles. The relative expression intensity of each gene to be tested for mice in the model group was calculated by the $2^{-\Delta \Delta \mathrm{Ct}}$ method through the measured cycle threshold value [17].

\section{Detection of protein expression in injured foot tissues by western blot}

The right hind plantar tissues of mice underwent tissue homogenization. Then, $1 \mathrm{~mL}$ of precooled lysate was added to each $100 \mathrm{mg}$ of tissue for a 15-minutes incubation on ice, and subsequently centrifuged at $10,000 \mathrm{rpm}$ at $4^{\circ} \mathrm{C}$ for 15 minutes. After centrifugation, the supernatant was removed, and the protein was quantified by the bicinchoninic acid method. The protein samples were separated by $10 \%$ sodium dodecyl sulfate-polyacrylamide gel electrophoresis. The proteins in the polyacrylamide gel were transferred to a nitrocellulose membrane. The membrane was blocked with $5 \%$ skimmed milk powder solution at room temperature for 1 hour and incubated overnight on a shaker with primary antibody at $4^{\circ} \mathrm{C}$. Subsequently, the membrane was washed three times with phosphate-buffered saline with Tween 20 (PBST) for 5 minutes each time. Then, secondary antibody was added, the membrane was incubated on a shaker for 2 hours, and was washed three times with PBST for 5 minutes each time to enhance the chemiluminescent agent's luminescence, development, and imaging [18].

\section{Statistical analysis}

Statistical software SPSS 17.0 (SPSS Inc., Chicago, IL, USA) was used for analysis, and the measurement data are expressed as the mean \pm standard deviation. The $t$-test was

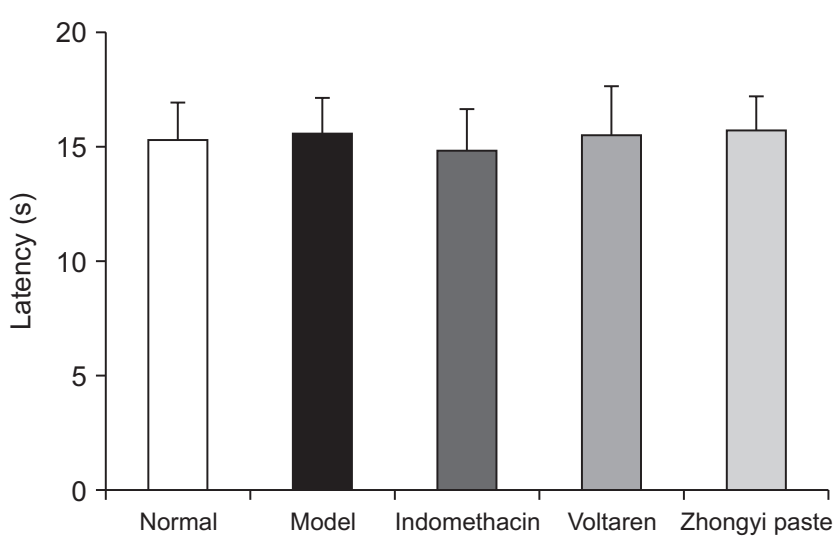

Fig. 2. Effects of Zhongyi paste on pain threshold in normal mice. Indomethacin: paw swollen mice treated with $10 \mathrm{mg} / \mathrm{kg}$ body weight indomethacin by gavage, Voltaren: paw swollen mice evenly applied with voltaren, Zhongyi paste: paw swollen mice evenly applied with Zhongyi paste. used for comparison between two samples, and the oneway analysis of variance (ANOVA) test was used for comparison between multiple samples. Duncan's new multiple range test distribution was used to test the hypothesis, and the total "false" error probability is adjusted according to the mean number to be tested, and the total "false" error probability does not exceed the set significance level of $P<$ 0.05 .

\section{RESULTS}

\section{Effects of drugs on the pain threshold in normal mice}

There was no significant difference in pain thresholds between groups without inducing foot swelling (Fig. 2). From this finding, we could assume that the individual differences between each group of mice would not have affected the results of other experiments in this study.

\section{Effects of drugs on the pain threshold in mice with carrageenan-induced foot swelling}

After inducing foot swelling, the pain threshold of the mice significantly decreased $(P<0.05$, Fig. 3). However, the pain threshold of the mice was increased after drug treatment. The effect of Zhongyi paste on raising the pain threshold of the mice was significantly $(P<0.05)$ greater than that of the other two drugs.

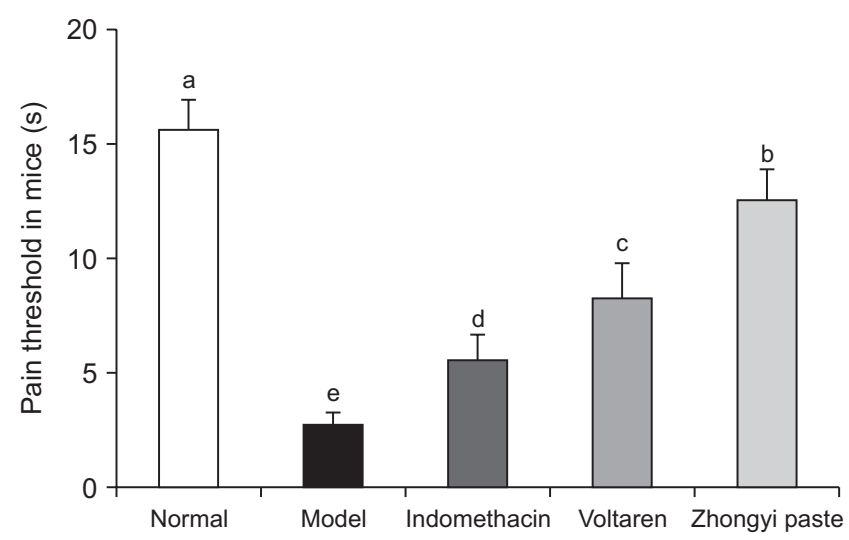

Fig. 3. Effects of Zhongyi paste on pain threshold in mice with carrageenan-induced foot swelling. Values presented are the mean \pm standard deviation. Indomethacin: paw swollen mice treated with $10 \mathrm{mg} / \mathrm{kg}$ body weight indomethacin by gavage, Voltaren: paw swollen mice evenly applied with voltaren, Zhongyi paste: paw swollen mice evenly applied with Zhongyi paste. ${ }^{a-e}$ Mean values with different letters in the bar are significantly different $(P<0.05)$ according to Duncan's new multiple range test. $\mathrm{a}<0.05$ vs. model group, $\mathrm{b}<0.05$ vs. model group, $\mathrm{c}<0.05$ vs. model group, $\mathrm{d}<0.05$ vs. model group, $\mathrm{e}<0.05$ vs. normal group. 


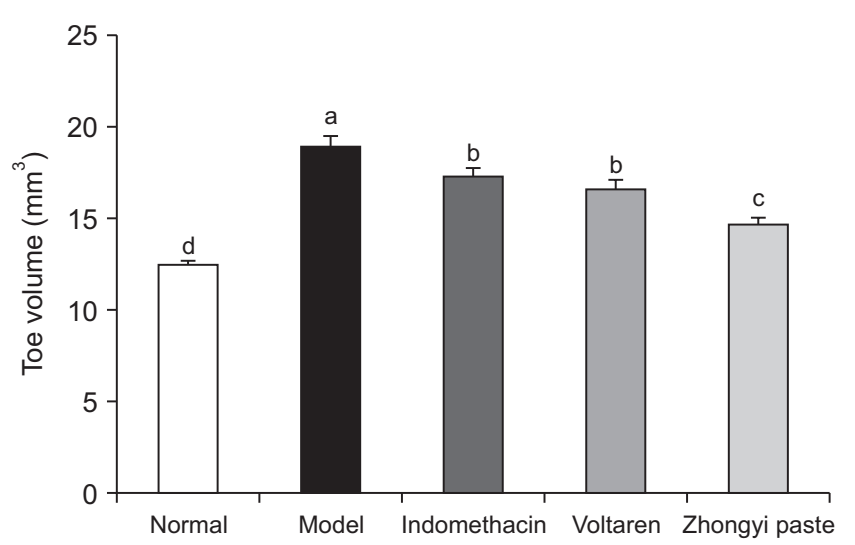

Fig. 4. Effects of Zhongyi paste on swelling degree of foot in carrageenan-induced foot swelling mice. Values presented are the mean \pm standard deviation. Indomethacin: paw swollen mice treated with $10 \mathrm{mg} / \mathrm{kg}$ body weight indomethacin by gavage, Voltaren: paw swollen mice evenly applied with voltaren, Zhongyi paste: paw swollen mice evenly applied with Zhongyi paste. ${ }^{\text {a-d }}$ Mean values with different letters in the bar are significantly different $(P<0.05)$ according to Duncan's new multiple range test. $a<0.05$ vs. normal group, $b<0.05$ vs. model group, $c<0.05$ vs. model group, $\mathrm{d}<0.05 \mathrm{vs}$. model group.

Table 3. Serum Levels of TNF- $\alpha$, IL-1 $1 \beta$, and $\mathrm{PGE}_{2}$ of Swelling and Inflammatory Foot Mice

\begin{tabular}{lccr}
\hline \multicolumn{1}{c}{ Group } & TNF- $\alpha(\mathrm{ng} / \mathrm{mL})$ & $\mathrm{IL}-1 \beta(\mathrm{ng} / \mathrm{mL})$ & $\mathrm{PGE}_{2}(\mathrm{pg} / \mathrm{mL})$ \\
\hline Normal & $132.34 \pm 8.73^{\mathrm{e}}$ & $177.94 \pm 9.47^{\mathrm{e}}$ & $59.90 \pm 4.33^{\mathrm{e}}$ \\
Model & $954.92 \pm 38.08^{\mathrm{a}}$ & $649.86 \pm 36.41^{\mathrm{a}}$ & $132.30 \pm 8.10^{\mathrm{a}}$ \\
Indomethacin & $568.61 \pm 40.91^{\mathrm{b}}$ & $497.51 \pm 16.56^{\mathrm{b}}$ & $97.33 \pm 8.37^{\mathrm{b}}$ \\
Voltaren & $431.67 \pm 40.04^{\mathrm{c}}$ & $439.61 \pm 13.40^{\mathrm{c}}$ & $88.46 \pm 5.12^{\mathrm{c}}$ \\
Zhongyi paste & $315.97 \pm 19.61^{\mathrm{d}}$ & $296.39 \pm 15.61^{\mathrm{d}}$ & $72.24 \pm 5.48^{\mathrm{d}}$ \\
\hline
\end{tabular}

Values are presented as mean \pm standard deviation.

TNF- $\alpha$ : tumor necrosis factor-alpha, IL-1 $\beta$ : interleukin-1 beta, PGE: prostaglandin $E_{2}$, Indomethacin: paw swollen mice treated with $10 \mathrm{mg} / \mathrm{kg}$ body weight indomethacin by gavage, Voltaren: paw swollen mice evenly applied with voltaren, Zhongyi paste: paw swollen mice evenly applied with Zhongyi paste.

${ }^{a-d}$ Mean values with different letters in the same column are significantly different $(P<0.05)$ according to Duncan's new multiple range test.

\section{Effect of drugs on swelling degree of the foot in mice with carrageenan-induced foot swelling}

The paw volume of the mice was measured by the foot volume meter, and the swelling degree in each group was compared (Fig. 4). Compared with the normal group (paw volume: $12.5 \pm 0.2 \mathrm{~mm}^{3}$ ), the swelling of the foot (paw volume: $18.9 \pm 0.6 \mathrm{~mm}^{3}$ ) in the carrageenan model group significantly increased $(P<0.05)$. Compared with the model group, the three drugs reduced the degree of swelling in the foot, and the effect of Zhongyi paste (paw volume: 14.7 $\left.\pm 0.3 \mathrm{~mm}^{3}\right)$ was the most robust, and was significantly $(P<$ 0.05 ) higher than that of indomethacin (paw volume: 17.3 $\pm 0.4 \mathrm{~mm}^{3}$ ) and voltaren (paw volume: $16.6 \pm 0.5 \mathrm{~mm}^{3}$ ).

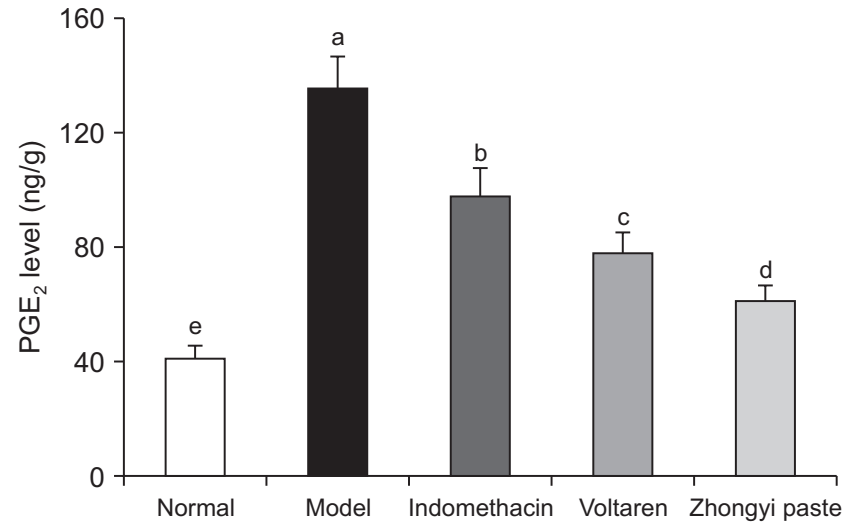

Fig. 5. Effects of Zhongyi paste on paw tissue prostaglandin $E_{2}\left(P_{G} E_{2}\right)$ levels in carrageenan-induced foot swelling mice. Values presented are the mean \pm standard deviation. Indomethacin: paw swollen mice treated with $10 \mathrm{mg} / \mathrm{kg}$ body weight indomethacin by gavage, Voltaren: paw swollen mice evenly applied with voltaren, Zhongyi paste: paw swollen mice evenly applied with Zhongyi paste. ${ }^{\text {ae }}$ Mean values with different letters in the bar are significantly different $(P<0.05)$ according to Duncan's new multiple range test. $a<0.05$ vs. normal group, $b<0.05$ vs. model group, $c<0.05$ vs. model group, $d<0.05$ vs. model group, $\mathrm{e}<0.05$ vs. model group.

\section{Effect of drugs on serum TNF- $\alpha, \mathrm{IL}-1 \beta$, and $\mathrm{PGE}_{2}$ cytokine levels in mice with carrageenan-induced foot swelling}

The experimental results show that the levels of TNF- $\alpha$ and IL-1 $\beta$ in the serum of normal mice were the lowest (Table 3), and the levels of foot swelling in the model group were the highest. All three drugs significantly $(P<0.05)$ reduced the serum levels of TNF- $\alpha$ and IL-1 $\beta$ in the mice as compared to those in the model group, and the effects of Zhongyi paste, voltaren, and indomethacin, in turn, increased.

\section{Effect of drugs on paw tissue $\mathrm{PGE}_{2}$ levels in mice with carrageenan-induced foot swelling}

Fig. 5 shows that the paw tissue $\mathrm{PGE}_{2}$ levels in mice with carrageenan-induced foot swelling (the model group) were highest (135.43 $\pm 10.95 \mathrm{ng} / \mathrm{g})$, and the levels in normal mice were the lowest (41.01 $\pm 4.26 \mathrm{ng} / \mathrm{g})$. Zhongyi paste (61.13 \pm $5.23 \mathrm{ng} / \mathrm{g})$, voltaren $(77.71 \pm 7.01 \mathrm{ng} / \mathrm{g})$, and indomethacin $(97.87 \pm 9.66 \mathrm{ng} / \mathrm{g})$ decreased the paw tissue $\mathrm{PGE}_{2}$ levels compared to the model group, and the effect of Zhongyi paste was stronger than that of voltaren or indomethacin.

\section{Effect of drugs on ERK1/2, COX-2, and $\mathrm{PGE}_{2}$ mRNA expression of paw tissues in mice with carrageenan-induced foot swelling}

Fig. 6 shows that carrageenan-induced foot swelling sig- 

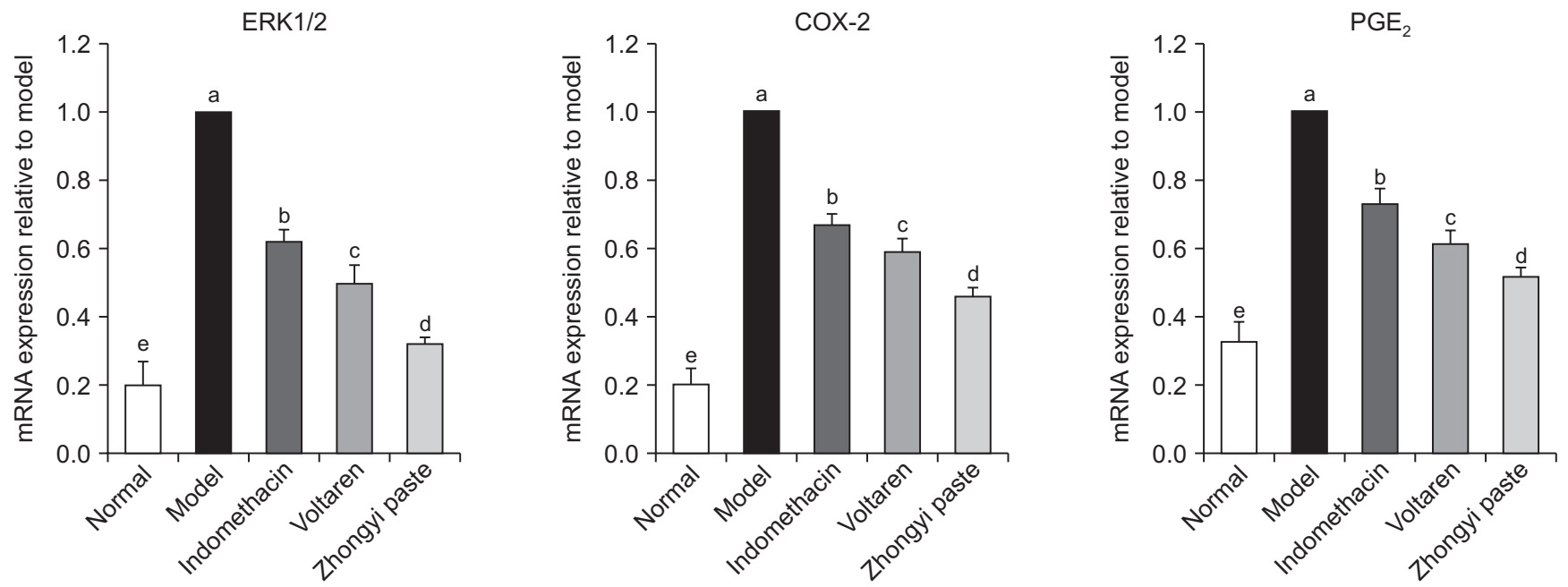

Fig. 6. Effects of Zhongyi paste on paw tissue extracellular signal-regulated kinase 1/2 (ERK1/2), cyclooxygenase-2 (COX-2), and prostaglandin $\mathrm{E}_{2}\left(\mathrm{PGE}_{2}\right)$ mRNA expression in carrageenan-induced foot swelling mice. Values presented are the mean \pm standard deviation. Indomethacin: paw swollen mice treated with $10 \mathrm{mg} / \mathrm{kg}$ body weight indomethacin by gavage, Voltaren: paw swollen mice evenly applied with voltaren, Zhongyi paste group: paw swollen mice evenly applied with Zhongyi paste. ${ }^{\text {ae }}$ Mean values with different letters in the bar are significantly different $(P<0.05)$ according to Duncan's new multiple range test. $\mathrm{a}<0.05 \mathrm{vs}$. normal group, $\mathrm{b}<0.05 \mathrm{vs}$. model group, $\mathrm{c}<0.05 \mathrm{vs}$. model group, $\mathrm{d}<0.05 \mathrm{vs}$. model group, $\mathrm{e}<0.05 \mathrm{vs.} \mathrm{model} \mathrm{group.}$
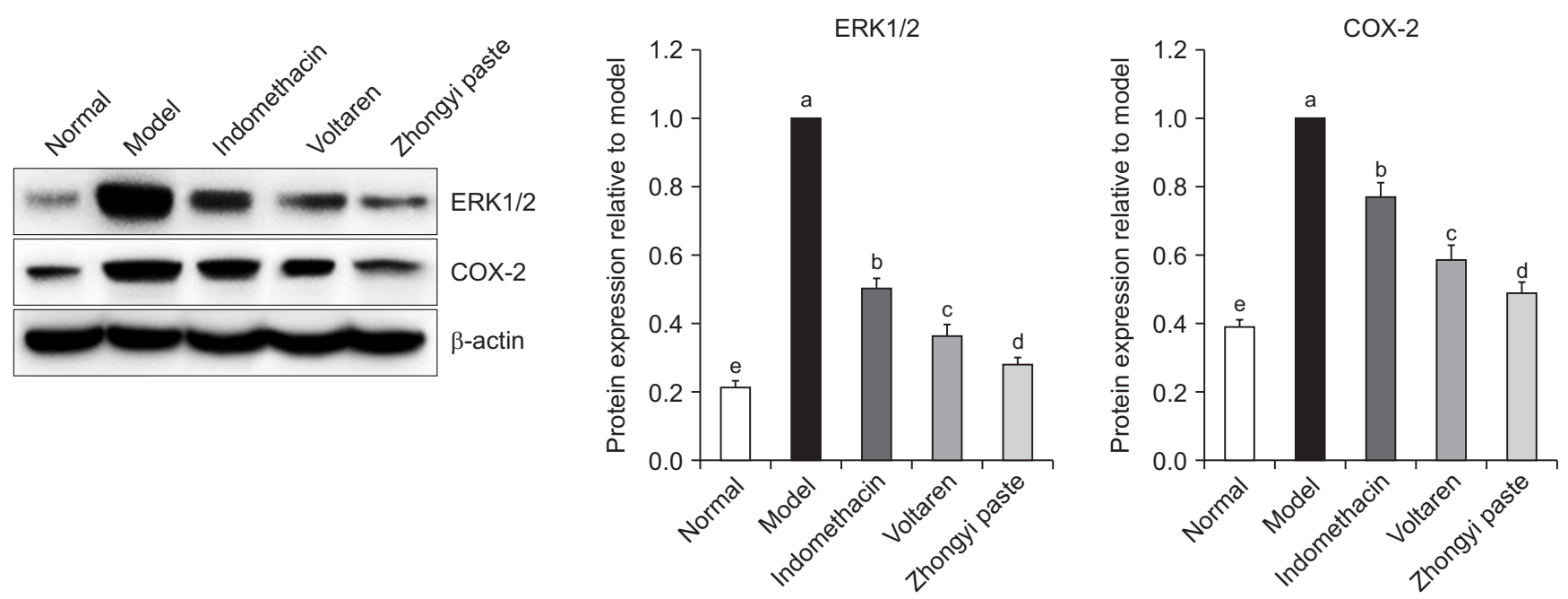

Fig. 7. Effects of Zhongyi paste on paw tissue extracellular signal-regulated kinase 1/2 (ERK1/2) and cyclooxygenase-2 (COX-2) protein expression in carrageenan-induced foot swelling mice. Values presented are the mean \pm standard deviation. Indomethacin: paw swollen mice treated with $10 \mathrm{mg} /$ kg body weight indomethacin by gavage, Voltaren: paw swollen mice evenly applied with voltaren, Zhongyi paste: paw swollen mice evenly applied with Zhongyi paste. ${ }^{\text {ae }}$ Mean values with different letters in the bar are significantly different $(P<0.05)$ according to Duncan's new multiple range test. a $<0.05$ vs. normal group, $\mathrm{b}<0.05$ vs. model group, $\mathrm{c}<0.05$ vs. model group, $\mathrm{d}<0.05$ vs. model group, $\mathrm{e}<0.05$ vs. model group.

nificantly $(P<0.05)$ increased expression of the ERK1/2, COX-2, and $\mathrm{PGE}_{2}$ mRNA in the paw tissues compared to the mice in the normal group. Zhongyi paste, voltaren, and indomethacin altered the expression of the mice with foot swelling so that it was similar to that of the normal mice, and the expression of mice in the Zhongyi paste group was most similar to that of mice in the normal group.

\section{Effect of drugs on ERK1/2, and COX-2 protein expression of paw paw tissues in mice with carrageenan-induced foot swelling}

Fig. 7 shows that the ERK1/2, and COX-2 protein expression of paw tissues in mice with carrageenan-induced foot swelling was highest, and was lowest in mice of the normal group. Zhongyi paste downregulated the expression compared to that of mice in the model group, and these downregulation abilities of Zhongyi paste were stronger 
that those of voltaren and indomethacin.

\section{DISCUSSION}

Carrageenan is an inflammatory agent that produces a stimulation reaction when subcutaneously injected into the paws of animals. It expands the capillaries of the feet of mice, increases the permeability of blood vessels, increases the inflammatory exudation, and causes a series of inflammatory reactions such as edema. Carrageenan can be used to establish a mouse foot swelling animal model to observe the pain and anti-inflammatory effect of the drug to be tested [19]. Therefore, this animal model was also used to observe the effect of Zhongyi paste. Indomethacin is an oral anti-inflammatory drug that can be used as a positive control drug for screening and activity evaluation [20]. Voltaren (diclofenac diethylamine emulsion) is a drug that is used externally to relieve mild to moderate pain in muscles, soft tissues, and joints, and also can be used as a positive control drug for research [21]. In this study, these two commonly used drugs were used as positive controls for comparing the efficacy of Zhongyi paste.

The acute inflammatory model of foot swelling induced by carrageenan results in a series of symptoms similar to human acute inflammation, such as edema, and it can also show an experimental decrease in the pain threshold [22]. In the current study, the paws of the model mice exhibited significant swelling, and the pain threshold significantly decreased. Zhongyi paste significantly inhibited the morphological changes of paws caused by swelling and reduced the pain in the feet of the mice, with effects that were stronger as compared to the other two drugs.

TNF- $\alpha$ stimulates endothelial cells, leading to inflammation, coagulation, and tissue damage, including tissue edema [23]. IL-1 $\beta$ attracts neutrophils, causes the release of inflammatory mediators, and stimulates a variety of different stromal cells to release proteolytic enzymes with various effects. IL-1 $\beta$ also causes synovial lesions (collagen destruction and bone resorption) in rheumatoid arthritis, and can also affect chondrocytes, fibroblasts, and bone metabolism [24]. In the process of acute inflammation, we can apply external agents that will activate monocyte macrophages, induce and release TNF- $\alpha$, IL-1 $\beta$, and other inflammatory factors, and then induce other cells to produce additional inflammatory factors $[25,26]$. In the current study, Zhongyi paste also promoted the decrease in TNF- $\alpha$ and IL- $1 \beta$ levels in mice, so as to reduce inflammation and foot swelling.

Pain is one of the main manifestations of inflammation, and inflammation is often accompanied by pain. Both interact with each other and contribute to the formation of inflammatory pain. Tissue damage induces an inflammatory response, and phospholipase A2 is then activated to release arachidonic acid from membrane phospholipids [27]. A series of prostaglandin derivatives and thromboxan A2 are produced from free arachidonic acid by COX [28]. $\mathrm{PGE}_{2}$ is a strong pro-inflammatory factor that can cause local vasodilation, increase microvascular permeability, increase the concentration of granulocytes, escalate the pain induced by bradykinin or histamine, and also cause fever. It can also induce the synthesis of COX-2, promote the production and release of inflammatory factors such as IL-6, TNF- $\alpha$, and IL-1 $\beta$, further enhance the intensity and duration of inflammation, enlarge the inflammatory response, and promote the amplification of the pain level [29-31]. In this study, it was found that the Zhongyi paste significantly inhibited the upregulation of COX-2 and $\mathrm{PGE}_{2}$ expression in mouse swollen paw tissues induced by carrageenan, and exerted anti-inflammatory and antihyperalgesic actions.

ERKs are important signal transduction proteins in the mitogen-activated protein kinase family that transmit mitogen signals. ERK1/2, as a mitogen-activated protein kinase, is expressed in response to extracellular stimuli. Activated ERK1/2-mediated inflammation or injury causes peripheral sensitization and hyperalgesia [32]. Overphosphorylation of ERK1/2 during inflammation stimulates the expression of COX-2 mRNA and protein to promote the release of $\mathrm{PGE}_{2}$, which in turn stimulates and mediates the occurrence and development of inflammatory pain $[33,34]$. In this study, we found that the ERK1/2 phosphorylation level substantially increased in injured tissues, while the intervention with Zhongyi paste inhibited the hyperphosphorylation of ERK1/2, blocked the signal transmission of inflammatory pain, reduced COX-2 synthesis, and effectively inhibited the expression of the inflammatory factor $\mathrm{PGE}_{2}$. The results showed that the anti-inflammatory and antihyperalgesic mechanism of Zhongyi paste might be closely related to the regulation of the ERK1/2-COX-2$\mathrm{PGE}_{2}$ signaling pathway.

In conclusion, the results showed that Zhongyi paste clearly decreased foot swelling in mice due to its anti-inflammatory and antihyperalgesic action. The mechanism of action of Zhongyi paste was derived from its ability to regulate the ERK1/2-COX-2-PGE 2 pathway. There was a more marked effect of Zhongyi paste when compared to that of the commonly used oral drug indomethacin and the externally used drug voltaren. Although the mechanism was elucidated, Zhongyi paste can be further optimized, so that the efficacy is improved, which will require additional studies for further discovery. 


\section{CONFLICT OF INTEREST}

No potential conflict of interest relevant to this article was reported.

\section{FUNDING}

This study was supported by funded by Chongqing Scientific Research Institute Performance Incentive Guidance Project (cstc2018jxjlX0003) and Funds for Construction of Chongqing Collaborative Innovation Center for Functional Food in Chongqing University of Education, China.

\section{ORCID}

Ailan Xiao, https://orcid.org/0000-0002-5151-7419

Chuncao Wu, https://orcid.org/0000-0002-5585-7955

Lei Kuang, https://orcid.org/0000-0002-5630-886X

Weizhong Lu, https://orcid.org/0000-0001-9672-4676

Xin Zhao, https://orcid.org/0000-0001-9798-7865

Zhiping Kuang, https://orcid.org/0000-0001-5006-3526

Na Hao, https://orcid.org/0000-0002-7389-9825

\section{REFERENCES}

1. Bundgaard L, Sørensen MA, Nilsson T, Salling E, Jacobsen S. Evaluation of systemic and local inflammatory parameters and manifestations of pain in an equine experimental wound model. J Equine Vet Sci 2018; 68: 81-7.

2. McCormack K. The spinal actions of nonsteroidal antiinflammatory drugs and the dissociation between their antiinflammatory and analgesic effects. Drugs 1994; 47 Suppl 5: 28-45.

3. DeHaven-Hudkins DL. Peripherally restricted opioid drugs: advances and retreats. Curr Opin Anaesthesiol 2003; 16: 5415.

4. Abramson SB. Treatment of gout and crystal arthropathies and uses and mechanisms of action of nonsteroidal antiinflammatory drugs. Curr Opin Rheumatol 1992; 4: 295-300.

5. Graham DM, McPherson H, Lieberman P. Skin testing in the evaluation of hymenoptera allergy and drug allergy. Immunol Allergy Clin North Am 2001; 21: 301-20.

6. Li YJ, Zhou J, Lei M. Clinical therapeutic study on the treatment of knee osteoarthritis with Zhongyi paste. Asia-Pac Tradit Med 2018; 8: 167-9.

7. Schrier DJ, Moniot S, Gluckman MI, Gilbertsen RB. The topical anti-inflammatory effects of a topical preparation of meclofenamic acid on carrageenan-induced footpad swelling in mice. J Pharm Pharmacol 1987; 39: 57-9.
8. Singh G, Katyal SL, Brown WE, Kennedy AL, Singh U, WongChong ML. Clara cell $10 \mathrm{kDa}$ protein (CC10): comparison of structure and function to uteroglobin. Biochim Biophys Acta 1990; 1039: 348-55.

9. Li YY, Huang SS, Lee MM, Deng JS, Huang GJ. Anti-inflammatory activities of cardamonin from Alpinia katsumadai through heme oxygenase-1 induction and inhibition of $\mathrm{NF}-\kappa \mathrm{B}$ and MAPK signaling pathway in the carrageenaninduced paw edema. Int Immunopharmacol 2015; 25: 332-9.

10. Minghetti L, Polazzi E, Nicolini A, Créminon C, Levi G. Upregulation of cyclooxygenase-2 expression in cultured microglia by prostaglandin E2, cyclic AMP and non-steroidal anti-inflammatory drugs. Eur J Neurosci 1997; 9: 934-40.

11. Martey CA, Pollock SJ, Turner CK, O’Reilly KM, Baglole CJ, Phipps RP, et al. Cigarette smoke induces cyclooxygenase-2 and microsomal prostaglandin E2 synthase in human lung fibroblasts: implications for lung inflammation and cancer. Am J Physiol Lung Cell Mol Physiol 2004; 287: L981-91.

12. Li W, Wu J, Yang Y, Pan L. Oxysophocarpine ameliorates carrageenan-induced inflammatory pain via adjusting ERK1/2COX-2-PGE2 pathway in mice. Animal Hus Feed Sci 2017; 38 : 15-9.

13. Wang L, Deng T, Zhang J, Chen Y. Resveratrol ameliorates inflammatory pain via inhibiting the COX-2/PGE2 signaling pathway in mice. Pharm Clin Chinese Mater Med 2017; 33: 35-8.

14. Liu Y, Zhang YJ, Yu Y, Li H, Liu L. Study on antipyretic, analgesic and anti-inflammatory effects of Fangfeng Jiere mixture. J Emerg Tradit Chinese Med 2019; 28: 1576-9.

15. Yang H, Cheng X, Wang YH, Du GH. Effects of esculin on the swelling of toes and inflammation induced by carrageenan in mice. Chinese J New Drugs 2016; 25: 2319-22.

16. Said R, Abdel-Rehim M, Sadeghi B, Al-Hashemi S, Hassan Z, Hassan M. Cyclophosphamide pharmacokinetics in mice: a comparison between retro orbital sampling versus serial tail vein bleeding. Open Pharmacol J 2007; 1: 30-35.

17. Liu B, Ma R, Zhang J, Sun P, Yi R, Zhao X. Preventive effect of small-leaved Kuding tea (Ligustrum robustum (Roxb.) Bl.) polyphenols on D-galactose-induced oxidative stress and aging in mice. Evid Based Complement Alternat Med 2019; 2019: 3152324.

18. Wang M, Wang J, Tan R, Wu Q, Qiu H, Yang J, et al. Effect of berberine on PPAR $\alpha$ /NO activation in high glucose- and insulin-induced cardiomyocyte hypertrophy. Evid Based Complement Alternat Med 2013; 2013: 285489.

19. Chou TC, Chang LP, Li CY, Wong CS, Yang SP. The antiinflammatory and analgesic effects of baicalin in carrageenanevoked thermal hyperalgesia. Anesth Analg 2003; 97: 1724-9.

20. Zhao Y, Yao Y, Zhang H, Wu C, Deng Z, Wang S. Pharmacokinetics and correlation between in vivo and in vitro transdermal penetration of indomethacin submicron emulsion gel. Chin J Mod Appl Pharm 2019; 36: 31-5. 
21. Hu G, Zhang L, Xu B, Ma F, Wang K, Lu Y, et al. Clinical study on diclofenac diethylamine emulsion delivery via nano plum-blossom needle for treatment of acute gouty arthritis. Chinese J Inform Tradit Chinese Med 2020; 27: 8-11.

22. Castro-Lopes JM, Tavares I, Tölle TR, Coimbra A. Carrageenan-induced inflammation of the hind foot provokes a rise of GABA-immunoreactive cells in the rat spinal cord that is prevented by peripheral neurectomy or neonatal capsaicin treatment. Pain 1994; 56: 193-201.

23. Kalyan Kumar G, Dhamotharan R, Kulkarni NM, Mahat MY, Gunasekaran J, Ashfaque M. Embelin reduces cutaneous TNF- $\alpha$ level and ameliorates skin edema in acute and chronic model of skin inflammation in mice. Eur J Pharmacol 2011; 662: 63-9.

24. Holmin S, Mathiesen T. Intracerebral administration of interleukin-lbeta and induction of inflammation, apoptosis, and vasogenic edema. J Neurosurg 2000; 92: 108-20.

25. Fang JQ, Liu F, Shao XM, Wu YY. [Effect of electroacupuncture on carrageenan-induced inflammation, IL-1beta and TNF-alpha concentrations and their mRNA expressions in toe tissue in rats]. Zhen Ci Yan Jiu 2007; 32: 224-8. Chinese.

26. Zhang M, Zhou J, Wang L, Li B, Guo J, Guan X, et al. Caffeic acid reduces cutaneous tumor necrosis factor alpha (TNF- $\alpha$ ), IL- 6 and IL-1 $\beta$ levels and ameliorates skin edema in acute and chronic model of cutaneous inflammation in mice. Biol Pharm Bull 2014; 37: 347-54.

27. Zambelli VO, Picolo G, Fernandes CAH, Fontes MRM, Cury Y. Secreted phospholipases $\mathrm{A}_{2}$ from animal venoms in pain and analgesia. Toxins (Basel) 2017; 9: 406.

28. Stachowska E, Dolegowska B, Dziedziejko V, Rybicka M,
Kaczmarczyk M, Bober J, et al. Prostaglandin E2 (PGE2) and thromboxane A2 (TXA2) synthesis is regulated by conjugated linoleic acids (CLA) in human macrophages. J Physiol Pharmacol 2009; 60: 77-85.

29. Lavigne P, Shi Q, Jolicoeur FC, Pelletier JP, Martel-Pelletier J, Fernandes JC. Modulation of IL-1beta, IL-6, TNF-alpha and PGE(2) by pharmacological agents in explants of membranes from failed total hip replacement. Osteoarthritis Cartilage 2002; 10: 898-904.

30. Damlar I, Esen E, Tatli U. Effects of glucosamine-chondroitin combination on synovial fluid IL-1 $\beta$, IL- 6 , TNF- $\alpha$ and PGE2 levels in internal derangements of temporomandibular joint. Med Oral Patol Oral Cir Bucal 2015; 20: e278-83.

31. Tipton DA, Flynn JC, Stein SH, Dabbous MKh. Cyclooxygenase-2 inhibitors decrease interleukin-1beta-stimulated prostaglandin E2 and IL-6 production by human gingival fibroblasts. J Periodontol 2003; 74: 1754-63.

32. Ciruela A, Dixon AK, Bramwell S, Gonzalez MI, Pinnock RD, Lee K. Identification of MEK1 as a novel target for the treatment of neuropathic pain. Br J Pharmacol 2003; 138: 751-6.

33. Li T, Hu J, Du S, Chen Y, Wang S, Wu Q. ERK1/2/COX-2/PGE2 signaling pathway mediates GPR91-dependent VEGF release in streptozotocin-induced diabetes. Mol Vis 2014; 20: 110921.

34. Lo HM, Chen CL, Tsai YJ, Wu PH, Wu WB. Thrombin induces cyclooxygenase-2 expression and prostaglandin E2 release via PAR1 activation and ERK1/2- and p38 MAPK-dependent pathway in murine macrophages. J Cell Biochem 2009; 108: 1143-52. 